\title{
THE IMPACT OF REMITTANCE FLOWS ON THE LABOUR MARKET OF ROMANIA AND THE EU COUNTRIES
}

\author{
Carmen Boghean ${ }^{1}$, \\ Mihaela State ${ }^{2}$
}

\begin{abstract}
Remittance flows have become a very important external source of financial flows for numerous countries, with visible effects on the economic growth and the increased financial stability of these countries. The labour force of Romania can be described as significantly diminishing, as a consequence of the workers' migration abroad and due to the increasing demographic aging of the population. The lack of well-trained labour resources leads to the decreased competitiveness throughout the European Union. The purpose of this paper is to analyse the effects of migration through remittance flows on the labour market, by using the data base of the World Bank and of the European Commission, for the period 2000-2013.
\end{abstract}

Key words: remittances, employment rate, labour market

JEL Codes: F24, F22, J61

\section{Introduction}

According to Eurostat, workers' remittances are defined as the transfers made by overseas resident workers to their relatives in their country of origin.

The relationship between remittances and economic growth has been and still is a topical subject among researchers in economics (Fayissa, F., Nsiah, C., 2010). The influence of migration and migration flows both on the sending as well as on the receiving country has already been acknowledged (Feraru, D. P., 2011). The research conducted on the effects of migration and remittances on the rural areas of Moldova has revealed that important remittance flows are directed towards younger and more skilled individuals, thus presuming that they should have a positive influence on an individual's ability to become employed (Walewski, M. et. al., 2008).

Money transfers to households are considered to encourage consumption, thus leading to at least a temporary alleviation of poverty (Roman, M., et. al., 2012). If these money transfers are being made with a certain frequency and in sufficient quantities to meet the consumption needs of the recipients, the effects could be negative on the labour market, as individuals no longer actively seek employment (Cox-Edwards, A., Rodriguez-Oreggia, E., 2006).

The objective of this paper is to identify the impact of remittances on the labour market, by analysing the relationship between the employment rate and the volume of remittance flows. In this respect, the first part of the paper focuses on presenting Romania's position among other EU countries in terms of the two variables under analysis.

\section{The main recipient countries of remittances}

The main European Union destination that Romanian immigrants prefer are Italy, Spain and Great Britain. Leaving for work abroad towards a certain destination is highly influenced by regional

\footnotetext{
${ }^{1}$ Faculty of Economics and Public Administration, Economics, Business Administration and Tourism Department, , University "Stefan cel Mare", Suceava, Romania, carmenb@seap.usv.ro

${ }^{2}$ Faculty of Economics and Public Administration, Economics, Business Administration and Tourism Department, , University "Stefan cel Mare", Suceava, Romania,_mihaelas@ seap.usv.ro
} 
and historical factors. Thus, workers from Walachia particularly leave for Spain (38\%), while those from Moldavia will mostly prefer Italy (28\%). Those who intend to leave for Great Britain are mostly from the north-east of the country. The three above mentioned destinations are preferred by individuals aged between 23 and 40 years, but Great Britain in particular attracts a younger segment of the population ( $44 \%$ of the Romanians arriving in the UK are aged between 23 and 30 years), while Italy is significantly preferred by people aged above 50 years.

Romania has long been one of the countries where the sheer volume of remittance flows amounts to rather high values, also being an important and increasing part of the growth of financial flows.

If we were to make an international level comparison in terms of the total remittance flows, in 2007, Romania was just below India, China, Mexico, Philippines, France, Germany, Poland, Spain and Nigeria - thus ranking among the top 10 remittance recipient countries. This consistent rise of remittances in Romania during years of constant economic growth seems to provide an additional reason why the Romanians' standard of living hasn't risen at the same time as economic growth; if it had, remittance shouldn't have risen as well during that same period.

Relative to the current account, remittances accounted for up to $90 \%$ for Romania (in 2002) or over 60\% (in 2003 and 2005), thus justifying the logic according to which they are an important source for reducing external deficit (Voinea, I., 2009).

In 2013, Romania ranked $8^{\text {th }}$ among EU countries in terms of the value of remittances, the first three positions going to France, Germany and Belgium. The lowest values have been recorded in countries like Cyprus or Malta.

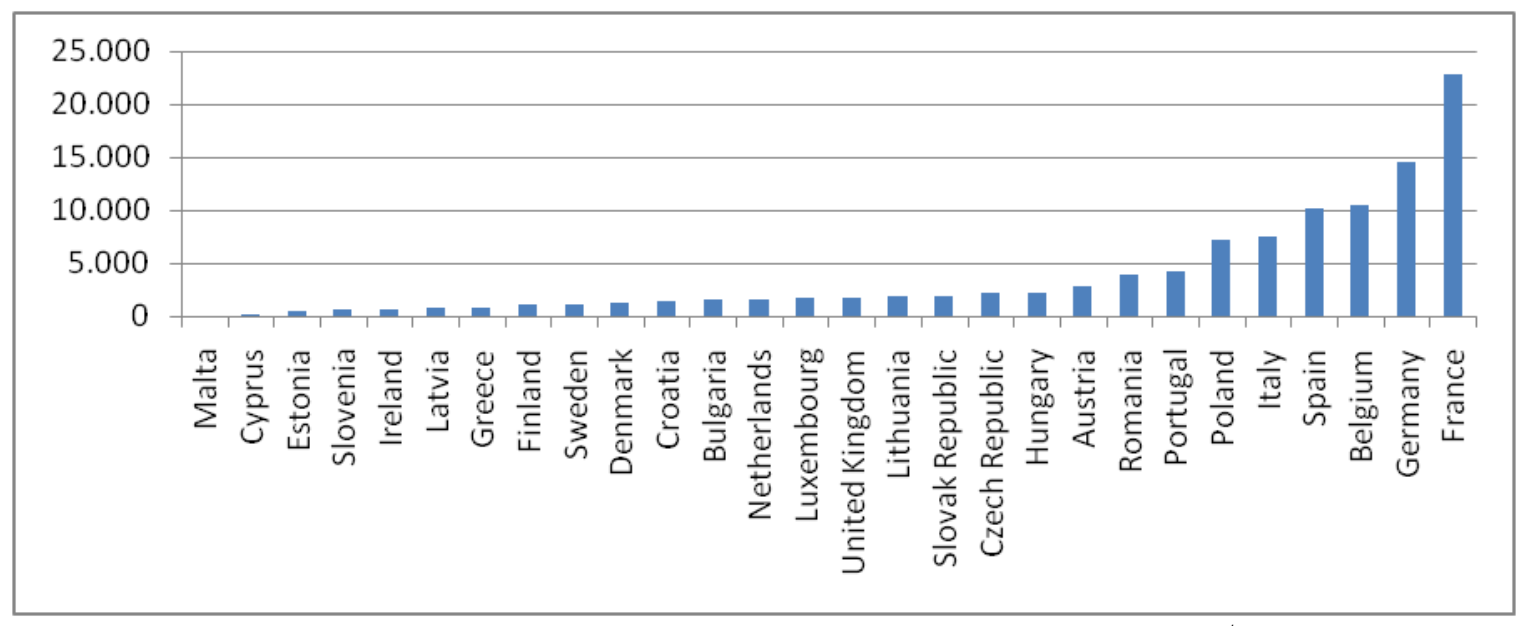

Fig.no.1 Migrant remittance inflows to EU countries in 2013 (mill. \$)
Source: developed based on the data available on http://data.worldbank.org/

Due to the financial crisis that has shaken the world in the past few years, Europe has undergone a dramatic decline in employment. Relative to the Gross Domestic Product, Europe is doing worse than the United States in terms of employment, while the European experience is highly unequal in each country. If Germany seems relatively unharmed, the countries on the outskirts of the EU are facing total disaster: in Italy, the unemployment rate among the young population amounts to $28 \%$, in Ireland up to $30 \%$, while in Spain, the worst case of all, the unemployment rate has reached $43 \%$. A great advantage for Europe would be that European states have stronger safety nets that in other parts of the world, and, thus, the consequences of unemployment are less serious. The universal nature of medical care prevents the loss of employment in EU countries from leading to the loss of health insurance (Krugman, P, 2012). 
The economic decline in Europe has had a differentiated impact on the component regions, since those EU countries that had the largest speculative bubbles before the crisis are confronted with the most serious economic decline and a high rate of unemployment.

As far as the employment rate is concerned, note that in 2013, Romania had one of the lowest values of this rate $(63,9 \%)$, as opposed to other EU countries. Countries such as Spain and Italy, with a high volume of remittances, have a rather low employment rate.

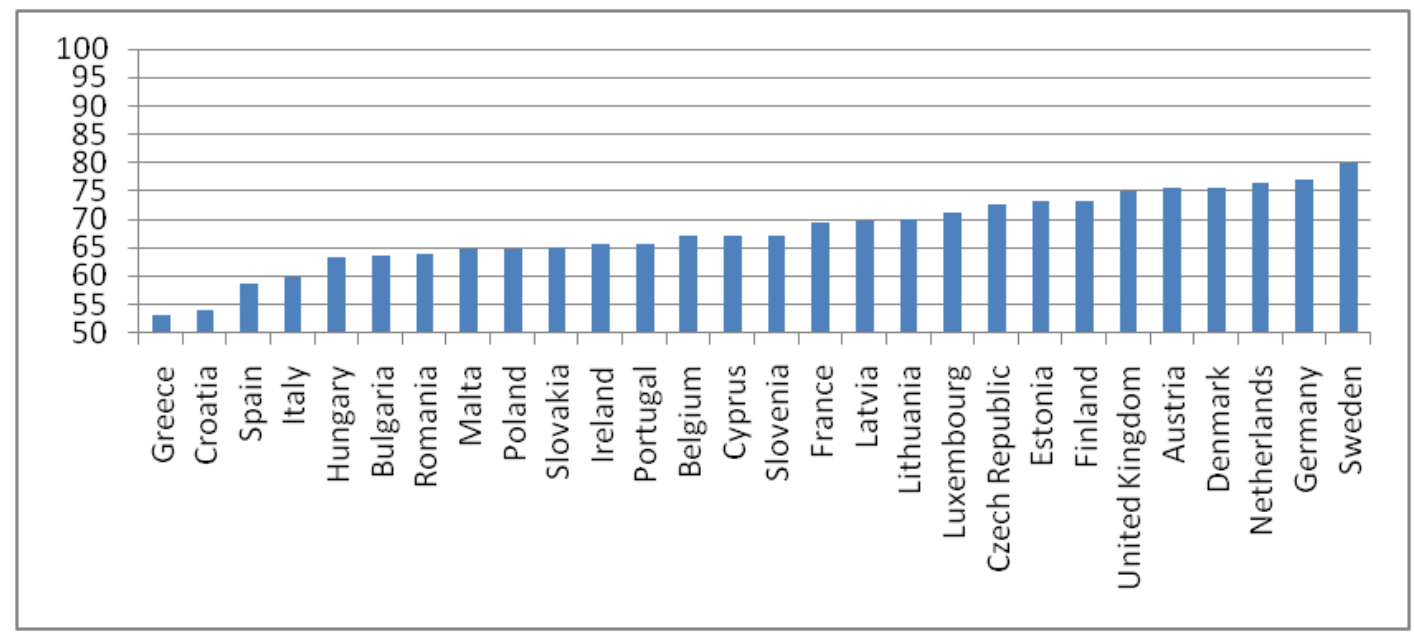

Fig. no. 2 Employment rate in EU countries in $2013(\%)$

Source: developed based on the data available on http://epp.eurostat.ec.europa.eu/portal/page/portal/eurostat/home/

A comparative analysis based on the data concerning the employment rate and the volume of remittances in EU countries in 2013, reveals the fact that Sweden has the highest employment rate but has a very low volume of remittances.

The extended weakening of the economy, caused by the financial crisis, affects a country's long term development potential. The prolonged economic decline affects the world through multiple channels, the most visible being the long term corrosive effect of unemployment: if people who have been out of employment for a long time start to seem insignificant, this leads to a long term decline of the active labour force and of the production capacity of the economy.

\section{Analysis of the relationship between the volume of remittances and the employment} rate in Romania during 2000-2013

The value of remittance inlfows in Romania in the period between 2000-2013 has had an ascending value until 2008, subsequently dropping to approximately to a half, according to the data available on the World Bank website. Going back to the year 2007, the amount of remittances relevant to the GDP in the top 10 states, except for Nigeria, was lower than the 5,1\% weight recorded in Romania. Many other states have a higher value, relevant to the GDP, with Tadjikistan (45\%) and Tonga (39\%) among the top ranking, and Moldova (34\%), Bosnia and Herzegovina (18\%), Serbia and Albania (14\%) in Europe. However, in the European Union, Romania ranks second, after Bulgaria (5,6\%). A higher weight of the remittances relevant to the GDP shows a dependency on this type of capital flows and a relative setback in the local economy. In 2013, the value of remittance inflows to Romania amounted to $\$ 862$ million, according to the data presented in Table 1.

As the volume of remittance inflows increased, their weight in the current account was declining; thus, the growth rate of remittances was slower than the augmentation of the trade imbalance, that it covered to an increasingly lower extent. Therefore, it is rather appropriate to 
wonder what is the destination of remittances and how beneficial such a highlevel of remittances actually is.

\begin{tabular}{|c|c|c|}
\hline Years & $\begin{array}{c}\text { Migrant remittance inflows } \\
\text { (US\$ million) }\end{array}$ & $\begin{array}{c}\text { Employment rate } \\
(\%)\end{array}$ \\
\hline $\mathbf{2 0 0 0}$ & 96 & 69,1 \\
\hline $\mathbf{2 0 0 1}$ & 116 & 63,3 \\
\hline $\mathbf{2 0 0 2}$ & 143 & 63,7 \\
\hline $\mathbf{2 0 0 3}$ & 124 & 63,5 \\
\hline $\mathbf{2 0 0 4}$ & 132 & 63,6 \\
\hline $\mathbf{2 0 0 5}$ & 4708 & 64,8 \\
\hline $\mathbf{2 0 0 6}$ & 6673 & 64,4 \\
\hline $\mathbf{2 0 0 7}$ & 8461 & 64,4 \\
\hline $\mathbf{2 0 0 8}$ & 9285 & 63,5 \\
\hline $\mathbf{2 0 0 9}$ & 4881 & 63,3 \\
\hline $\mathbf{2 0 1 0}$ & 3879 & 62,8 \\
\hline $\mathbf{2 0 1 1}$ & 3889 & 63,8 \\
\hline $\mathbf{2 0 1 2}$ & 3674 & 63,9 \\
\hline $\mathbf{2 0 1 3}$ & 3862 & 6 \\
\hline
\end{tabular}

Table no. 1 The evolution of remittance inflows to Romania and the employment rate of the population during 20002013

Source: http://epp.eurostat.ec.europa.eu/portal/page/portal/eurostat/home/ http://data.worldbank.org/

The employment rate of the population in Romania has declined from $69,1 \%$ in 2000 , to $63,9 \%$ in 2013 . In order to identify a connection between the volume of remittance inflows and the employment rate of the population, we have used the Pearson correlation coefficient. The obtained results were summarised in Table no. 2.

\begin{tabular}{|ll|c|c|}
\hline & & $\begin{array}{c}\text { Migrant } \\
\text { remittance inflows }\end{array}$ & Employment rate \\
\hline Migrant remittance inflows & Pearson Correlation & 1 & $-0,292$ \\
& Sig. (2-tailed) & & 0,311 \\
& $\mathrm{~N}$ & 14 & 14 \\
\hline Employment rate & Pearson Correlation & $-0,292$ & 1 \\
& Sig. (2-tailed) & 0,311 & 14 \\
\hline
\end{tabular}

Table no. 2 The Pearson correlation coefficient

Source: calculations based on the data from Table no. 1, by means of the SPSS 17 programme

The value arrived at for the Pearson correlation coefficient shows the presence of an indirect and insignificant relationship between the employment rate and migrant remittance inflows to Romania. The lack of well paid jobs and the difficulties related to ensuring a decent standard of living urges a segment of the population to migrate to EU countries where they can find adequate conditions for personal and professional development. Their remittances to their families leads to increased consumption and investments, but have, in certain cases, some negative effects, as they do not 
encourage employment. We can ascertain that a low rate of employment leads to increased migration, thus engaging a large volume of migrant remittances. At the same time, the high volume of remittances has certain negative effects on the domestic labour market, as the population refuses to accept insufficiently paid jobs.

Among the advantages of remittances, we can mention: they reduce currency restrictions in the economy, are autonomous, are a potential source of savings and investments, increase the standard of living of the recipients, augment the national revenue, improve the distribution of income (if the migration is stronger among the poorer and less skilled population), create a social safety net that reduces the unemployment and inequality related tensions. And, from the standpoint of the balance of payments, remittances enable the financing of imports and the reduction of the current account deficit.

There are opinions according to which remittances do not influence the level of economic development since they are mainly used for consumption. For instance, the World Bank calculated that $20 \%$ of the household consumption in Albania of Moldova is accounted for from remittances, while UNCTAD estimated that remittances account for over $30 \%$ of household consumption. In practice, there is a strong correlation between remittances and trade deficit, which is explained by the very fact that remittances are used for financing consumption and the consumer goods mainly come from imports; households that receive remittances particularly spend more than $60 \%$ more on clothing and footwear that households with no such sources of income.

Another reason for the strong correlation between remittances and the trade deficit is that, since they are capital inflows, remittances increase the value of the national currency and thus imports become cheaper and exports become more expensive.

Even though they apparently finance the trade deficit and help reduce the current account deficit, the reality is that most remittances that are used for consumption create a trade deficit and deepen the current account deficit. They do not engage the economy, since they enter the country on the one hand and exit the country on the other hand through the payment of imports, and a part of remittances that does goes to investments is actually spent on counterproductive or personal investments, particularly in the real estate industry. Mintchev and Boshnakov (2006), have conducted a study on Bulgaria and have found that remittances are spent on consumer goods, personal car purchases and real estate purchases.

In a research analysis published under the aegis of the IMF (Chami et al., 2008) the influence of remittances on economic growth is denied, due to the very fact that they are not directed towards investments: "Remittances are not necessarily associated with an increase in domestic investments or with a more efficient allocation of domestic investments. The remittance beneficiaries replace their employment related revenues with these transfers and, since labour and capital are complementary factors of production, this has a negative effect on the capital accumulation rate. Analyses show that remittances do not have a statistically significant effect on economic growth." Grigorian and Melkonyan (2008) confirm, with data for Armenia, that the remittance beneficiaries choose to work less.

Moreover, the remittance beneficiaries choose to maintain a subsistence mentality. In theory, several studies start from the principle that an increase in remittances enables the alleviation of public expenses for social assistance, since remittances improve the standard of living of the recipients and they no longer require the same level of government assistance (Orozco, M., Gay Ellis, C., 2013). This theory hasn't been proved in Romania yet, since social security expenses have quickly increased as remittances have boomed.

Another unfortunate consequence of remittances is the reduction of incentives for structural reforms, due to the safety net they provide for recipients. Additionally, remittances increase the government's proneness to borrow, which is not always a good thing. Thus, the government fends social pressures and postpones structural reforms until the emergence of an economic crisis renders such pressures and reforms imminent. 
One should not overlook either the medium and long term negative effect on the GDP, as the brain drain (migration of the highly qualified work force) prevents the contribution of this category to the augmentation of the gross added value to the economy.

Remittances not only create external deficit in their turn, but the remittance capital inflows are much less predictable and much more volatile than was anticipated. Remittances practically stalled in 2008 in Romania, as compared to 2007, and, in 2009 they have dropped to one third (during the first seven months of the year). The unfavourable external circumstances have affected the migrants' ability to save and to send money back home. Under such circumstances, we identify the similarity between remittances and speculative capital: both are external savings financing domestic demand and causing the current account deficit to augment. Remittances are unpredictable, as they depend on exogenous factors that are often rather difficult to control.

\section{Conclusions}

Migrant remittances consist of labour related revenues that are part of the net factor income, and of current transfers that are part of the net cash transfers. The net factor income and the net cash transfers are part of the current account. Migrant remittances enable the reduction of the current account deficit but do not "finance" it.

Even though Romania has long been one of the countries where the amount of remittances reaches rather high values, the employment rate of the population is one of the lowest as compared to other countries of the European Union.

The analysis of the volume of remittances inflows in Romania for the period 2000-2013 has revealed an important increase until 2008, and a subsequent reduction to almost one half of such inflows, according to the data available on the World Bank website. During the same period, the employment rate of the population in Romania has declined from $69,1 \%$ in 2000 , to 63,9\% in 2013. In order to identify a connection between the volume of remittances and the employment rate of the population, we have used the Pearson correlation coefficient. The findings have revealed a reversed connection that is statistically irrelevant, between the employment rate and the migrant remittance inflows in Romania. One possible cause that has been identified is the lack of sufficiently paid jobs and the difficulties related to ensuring a decent standard of living, thus leading to the migration of the workforce to more developed countries of the European Union. The remittance inflows to their families leads to increased consumption and investments, but may sometimes also have a negative influence since they lead to a lack of employment on the domestic labour market.

Based on the results obtained after using the Pearson correlation coefficient, we can conclude that there is a certain negative correlation between the employment rate and the volume of remittance inflows in Romania. In other words, a low employment rate leads to an increased migration rate, thus triggering a high level of remittance inflows. At the same time, the high remittance inflows have certain negative effects on the domestic labour market as the population refuses employment in insufficiently paid jobs.

The economic depression in Europe has led to fiscal crises of unforeseen proportions. The reaction to these fiscal crises has boosted unemployment to alarming rates throughout Europe.

The strange mixture of unity and lack thereof that is currently identified in Europe - as most countries adopt common currencies without having created the type of political and economic union that such a currency unit requires, thus leading to prolonged frailness and crises - greatly endanger the fate of people without employment.

In terms of demographics, the consequences of migration are rather significant. The migrants' tendency to reside permanently in their destination countries is well known and this creates considerable losses in demographics. This loss subsequently results in a decline of economic growth and, in certain situations, can even lead to a decline in economic activities. 


\section{References}

1. Chami, R., et al., (2008), Macroeconomic Consequences of remittances, IMF Occasional Paper 259;

2. Cox-Edwards, A., Rodriguez-Oreggia, E., (2006), The Effect of Remittances on Labour Force Participation: An analysis based on Mexico's 2002 ENET", http://www.iza.org/conference_files/worldb2006/rodriguez-oreggia_e2730.pdf, 17.09.2014;

3. Fayissa, F., Nsiah, C., (2010), The Impact of Remittances on Economic Growth and Development in Africa, New York, American Economist;

4. Feraru, D. P., (2011), Migraţie şi dezvoltare. Aspecte socioeconomice şi tendinţe, Iaşi, Editura Lumen;

5. Krugman, P., (2012), Opriţi această depresiune - acum!, Bucureşti, Editura Publica;

6. Orozco, M., Gay Ellis, C., (2013), Impact of remittances in developing countries, The InterAmerican Dialogue;

7. Roman, M., Goschin, Z., Roman, Z. (2012), Emigraţia românescă: implicaţii economice şi demografie, Bucureşti, Editura ASE;

8. Roman, M., Voicu, C., (2010) Câteva efecte socioeconomice ale migraţiei forţei de muncă asupra ţărilor de emigraţie. Cazul României, Economie teoretică şi aplicată, Volumul XVII (2010), No. 7(548), pp. 50-65, http://store.ectap.ro/articole/484_ro.pdf, 17.09.2014;

9. Walewski, M., Sandu M., Mincu, G., Hristev, E., Matysiewicz, B., (2008), Efectele migraţiei în zonele rurale din Moldova. Studiu de caz privind gestionarea migraţiei în Polonia, Centrul de Bucureşti, Investigaţii Sociale şi Economice;

10. Voinea, L., (2009), Sfârşitul economiei iluziei, Bucureşti, Editura Publica;

11. World Bank, (2008), Migration and Remmitances Factbook;

12. http://epp.eurostat.ec.europa.eu/portal/page/portal/eurostat/home/, 20.09.2014

13. http://data.worldbank.org/, 21.09.2014

\section{Acknowledgement}

This paper has been financially supported within the project entitled ,SOCERT. Knowledge society, dynamism through research", contract number POSDRU/159/1.5/S/132406. This project is cofinanced by European Social Fund through Sectorial Operational Programme for Human Resources Development 2007-2013. Investing in people!" 